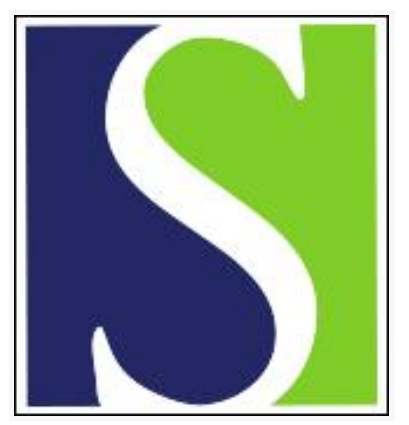

Scand J Work Environ Health 1993;19(6):382-389

https://doi.org/10.5271/sjweh.1458

Issue date: 01 Dec 1993

\title{
Cancer among farmers in central Italy.
}

by Forastiere F, Quercia A, Miceli M, Settimi L, Terenzoni B, Rapiti E, Faustini A, Borgia P, Cavariani F, Perucci CA

Affiliation: Regional Epidemiologic Unit, Latium Health Authority, Rome, Italy.

The following article refers to this text: 2016;42(2):144-152

This article in PubMed: www.ncbi.nlm.nih.gov/pubmed/8153589

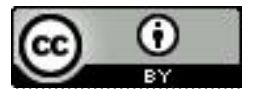




\title{
Cancer among farmers in central Italy
}

\author{
by Francesco Forastiere, MD, ${ }^{1}$ Augusto Quercia, MD, ${ }^{2}$ Maria Miceli, BSc, ${ }^{1}$ Laura Settimi, MD ${ }^{3}$ \\ Brunella Terenzoni, BSc, ${ }^{2}$ Elisabetta Rapiti, MD, ${ }^{1}$ Annunziata Faustini, MD, ${ }^{1}$ Piero Borgia, MD, ${ }^{1}$ \\ Fulvio Cavariani, BSc, ${ }^{4}$ Carlo A Perucci, MD ${ }^{1}$
}

\begin{abstract}
FORASTIERE F, QUERCIA A, MICEII M,SETTIMI L, TERENZONI B, RAPITI E, FAUSTINI A, BORGIA P, CAVARIANI F, PERUCCI CA. Cancer among farmers in central Italy. Scand $J$ Work Environ Health 1993;19:382-9. This case-referent study evaluated cancer risks among farmers in central Italy. Cancer cases $(\mathrm{N}=1674,17$ sites) were selected from all deceased men aged 3580 years; a random sample of 480 decedents formed the reference series. Farmers had a decreased risk of lung and bladder cancer and melanoma and nonsignificant excess risks for stomach, rectal, kidney, and nonmelanoma skin cancer. Stomach and kidney cancer were significantly increased among the farmers with $>10$ years' experience, and stomach, rectal, and pancreatic cancer were increased among licensed pesticide users with $>10$ years' experience. Possible relationships emerged between specific crops and cancer: fruit and colon and bladder cancer, wheat and prostate cancer, olives and kidney cancer, and potato and kidney cancer. The results regarding stomach, pancreatic, lung, bladder, and prostate cancer and melanoma congrue with earlier results. The kidney cancer excess, the association of colon and bladder cancer with orchard farming, and the excess of rectal cancer among licensed farmers are new and unexpected findings.
\end{abstract}

Key terms: agriculture, case-referent study, colon cancer, exposure assessment, kidney cancer, occupational cancer, pancreatic cancer, pesticides, stomach cancer.

Cancer occurrence among farmers has been extensively studied because of the potentially hazardous substances farmers are exposed to (eg, pesticides, solvents, paints, and engine exhaust). Although the most common cancer types (eg, lung cancer) seem to be underrepresented in this group, some rarer forms are seen in excess, perhaps as a result of pesticide exposure $(1,2)$. Results from different countries are conflicting, however. Even within the United States, excesses of cancer mortality among farmers are not entirely consistent by gender, race, or geographic area (3).

The extent of exposure to pesticides, as well as to other chemicals, is not homogeneous among farmers. Instead it depends on such factors as crop type, climatic conditions, chemicals available on the market, specific tasks performed, and protective equipment used. Exposure evaluation in analytical studies of cancer among farmers is thus a critical issue (4), and exposure assessment is often more qualitative than quantitative. The present case-referent study was conducted in a province of central Italy to study specific cancer sites among farmers in comparison with those among nonfarmers. On the assumption that farmers growing the same agricultural product

\footnotetext{
1 Regional Epidemiologic Unit, Latium Health Authority, Rome.

Local Health Unit VT-2, Tarquinia-VT.

Istituto Superiore di Sanitá, Rome.

Local Health Unit VT-5, Civitacastellana-VT, Italy.
}

Reprint requests to: Dr F Forastiere, Osservatorio Epidemiologico Regionale, Via Santa Costanza, 53, I-00198 Rome, Italy. within a defined geographic area during a specific period will tend to share similar work conditions, including exposure to chemicals, the relationship between cancers and various crops raised by agricultural workers in the area was studied.

\section{Subjects and methods}

\section{Selection of cases and referents}

The study concerned the population of the Viterbo Province, located northwest of Rome and comprising about 250000 inhabitants. The area has an agricultural tradition, with only one industrialized town (containing ceramics factories). Farms mainly concentrate on raising typical products of the Mediterranean area: wheat, olives, and grapes. There are also zones dedicated to a variety of other crops: hazelnuts, fruit, potatoes, corn (maize), and strawberries.

The regional mortality file, available for the period 1980-1986, was the source for selecting the cases and referents. The cases included 1674 cancer deaths among men aged 35-80 years who had resided in the 59 rural municipalities of the province (the main town, Viterbo, was excluded). The following tumors were included in the case series (table 1): esophagus, stomach, colon, rectum, pancreas, larynx, lung, prostate, bladder, kidney and brain cancer, melanoma, nonmelanoma skin cancer, non-Hodgkin's lymphoma, Hodgkin's lymphoma, multiple myeloma, and leukemia. A random sample of 480 individuals was drawn as the reference series from those deceased from all causes (including cancer deaths). Personal data and residence history of all of 
the subjects were ascertained from the municipal registry offices.

\section{Exposure data}

The identity of farmers, for both the cases and the referents, was ascertained from the register of the local farmers' pension fund (SCAU and INPS, Viterbo). This register has records of farmers and agricultural workers resident in the province, and the pension contribution for each year worked as a farmer or agricultural worker is annotated. Complete data were available from 1953 to 1985 , and a subject was classified as a farmer if he was present for at least one year in the register during this period. All other subjects were classified as nonfarmers. In order that a latency time restriction could be applied, those who were registered as farmers only during the 10 years before their date of death were considered nonfarmers. Duration of farming was taken as the total years registered as a farmer in the pension fund register between 1953 and 10 years prior to death.

A national law passed in 1969 requires a special license to purchase and use pesticides of high levels of toxicity (median lethal dose $<500 \mathrm{mg} \cdot \mathrm{kg}^{-1}$ in oral administration to rats). The provincial inspectorate of agriculture provided a list of all individuals (about 6000 ) who had been licensed as pesticide users during the first years of the law's application, 19711972. Cases and referents on this list were considered to be licensed pesticide users.

Expert agronomists from the local farmers' union were asked to provide an estimate of the prevalence of different crops in each municipality of the prov- ince during the study period. The main crops were considered (wheat, grapes, olives, hazelnuts, fruit, potatoes, corn, and strawberries) over five calendar periods (1950-1955, 1956-1960, 1961-1965, 1966-1970, and 1971-1975). On the basis of historical data available from the local farmers' union, the agronomists gave a score of $0-3$ concerning the likelihood of each of the eight different crops, specific for each of the 59 municipalities and for the five calendar periods; a crop rated zero for a given period was very unlikely to have been raised by anyone in the municipality, while one rated 3 was grown by virtually every farmer in the area. On the basis of the matrix of scores ( 5 periods, 8 crops, 59 municipalities), individual indices of work with a particular crop were calculated. For a specific calendar period, the individual's index was the product of his years of farming and the agronomists' score for the given crop. The individual cumulative "exposure index" was the sum of the period-specific indices. For example, a subject whose farming activity was registered from 1958 trough 1966 (ie, 0 years, 3 years, 5 years, 1 year, 0 years, in each of the 5 calendar periods), in a municipality where the scores for hazelnuts were $1,2,1,0,0$ for the five periods, had a cumulative "exposure index" for hazelnuts equal to $11[(0 \times 1)+(3 \times 2)+(5 \times 1)+(1 \times 0)+(0 \times 0)]$. The estimates of the exposure indices were made blindly with regard to case versus reference status.

Cumulative exposure indices were categorized according to cutoff points determined by the exposure distribution of the referents. For wheat, grapes, and olives, the most widespread agricultural products, subjects below the median were classified as unex-

Table 1. Case-referent data on the association between farming, duration of farming ( $\leq 10,>10$ years), and different cancer sites with nonfarmers as the reference category. [OR $=$ Mantel-Haenszel odds ratio adjusted for age $(35-49,50-59,60-69$, $70-80$ years), $90 \% \mathrm{Cl}=$ exact $90 \%$ confidence intervals]

\begin{tabular}{|c|c|c|c|c|c|c|c|c|c|c|}
\hline & \multirow{3}{*}{$\begin{array}{c}\text { Nonfarmers } \\
\text { (N) }\end{array}$} & \multicolumn{9}{|c|}{ Farmers } \\
\hline & & \multicolumn{3}{|c|}{$\leq 10$ years } & \multicolumn{3}{|c|}{$>10$ years } & \multicolumn{3}{|c|}{ Total } \\
\hline & & $\mathbf{N}$ & OR & $90 \% \mathrm{Cl}$ & $\mathrm{N}$ & OR & $90 \% \mathrm{Cl}$ & $N$ & OR & $90 \% \mathrm{Cl}$ \\
\hline \multicolumn{11}{|l|}{ Cases } \\
\hline Esophagus & 21 & 6 & 0.50 & $0.19-1.19$ & 17 & 1.02 & $0.54-1.91$ & 23 & 0.79 & $0.45-1.41$ \\
\hline Stomach & 113 & 75 & 1.01 & $0.72-1.41$ & 119 & $1.38^{*}$ & $1.03-1.87$ & 194 & 1.21 & $0.93-1.58$ \\
\hline Colon & 48 & 23 & 0.76 & $0.46-1.25$ & 36 & 0.93 & $0.60-1.43$ & 59 & 0.86 & $0.59-1.26$ \\
\hline Rectum and sigma & 21 & 19 & 1.40 & $0.76-2.58$ & 24 & 1.45 & $0.82-2.59$ & 43 & 1.44 & $0.87-2.40$ \\
\hline Pancreas & 29 & 17 & 0.95 & $0.52-1.71$ & 20 & 0.88 & $0.50-1.54$ & 37 & 0.93 & $0.58-1.49$ \\
\hline Larynx & 30 & 19 & 1.02 & $0.57-1.80$ & 22 & 0.94 & $0.54-1.61$ & 41 & 1.00 & $0.63-1.59$ \\
\hline Lung & 245 & 103 & $0.70^{*}$ & $0.52-0.93$ & 160 & 0.81 & $0.62-1.05$ & 263 & $0.76^{\star}$ & $0.61-0.96$ \\
\hline Melanoma & 11 & 1 & $0.16^{*}$ & $0.01-0.94$ & 2 & $0.22^{*}$ & $0.03-0.85$ & 3 & $0.19^{\star}$ & $0.05-0.63$ \\
\hline Nonmelanoma skin & 1 & 3 & 4.43 & $0.46-120$ & 3 & 3.76 & $0.41-98.2$ & 6 & 4.34 & $0.66-100$ \\
\hline Prostate & 46 & 23 & 0.66 & $0.39-1.10$ & 49 & 1.25 & $0.83-1.89$ & 72 & 0.99 & $0.68-1.44$ \\
\hline Bladder & 43 & 14 & $0.54^{*}$ & $0.29-0.98$ & 22 & 0.62 & $0.37-1.03$ & 36 & $0.58^{\star}$ & $0.38-0.90$ \\
\hline Kidney & 15 & 5 & 0.67 & $0.22-1.78$ & 21 & $2.00^{\star}$ & $1.03-3.94$ & 26 & 1.39 & $0.75-2.64$ \\
\hline Brain & 13 & 1 & $0.16^{\star}$ & $0.01-0.93$ & 9 & 1.04 & $0.43-2.44$ & 10 & 0.67 & $0.29-1.50$ \\
\hline Non-Hodgkin's lymphoma & 13 & 3 & 0.35 & $0.08-1.14$ & 8 & 0.80 & $0.33-1.87$ & 11 & 0.59 & $0.27-1.28$ \\
\hline Hodgkin's lymphoma & 5 & 3 & 1.24 & $0.25-5.34$ & 2 & 0.62 & $0.08-3.14$ & 5 & 0.84 & $0.23-3.04$ \\
\hline Multiple myeloma & 6 & 4 & 1.15 & $0.29-4.10$ & 4 & 0.76 & $0.20-2.69$ & 8 & 0.95 & $0.33-2.79$ \\
\hline Leukemia & 24 & 14 & 0.80 & $0.41-1.52$ & 24 & 1.29 & $0.74-2.27$ & 38 & 1.07 & $0.66-1.77$ \\
\hline Referents & 188 & 121 & . & . & 153 & - & . & 274 & . & . \\
\hline
\end{tabular}

${ }^{*} \mathrm{P}<0.10$ (two-sided). 
posed, while subjects above the median were placed in the "any exposure" group. Individuals above the referents' upper quartile were considered as having "high exposure." For the other five crops, which have a more limited diffusion in the area, all persons with a nonzero cumulative index were classified in the "any exposure" group and a cutoff point at the median of the distribution among the referents indicated membership in the group with "high exposure."

\section{Data analysis}

Some 17 categories of cancer sites were first considered, as indicated in table 1 . The associations were studied through comparisons of the cases of cancer at each site with the entire reference group for the various exposures of interest. The reference group was basically the same for each cancer site, except that, in each run, any subjects deceased from the specific cancer site were removed from the reference series.

The data analysis was conducted in several stages. First, farmers were compared with nonfarmers in calculations of age-adjusted odds ratios (OR) (age in four classes) according to the Mantel-Haenszel technique (5) together with exact two-sided $90 \%$ confidence intervals $(90 \% \mathrm{CI})$. In addition, farmers with a license for pesticide use were compared with both nonfarmers and other farmers using the same Mantel-Haenszel procedure. Second, the analysis was restricted to farmers; for all cancer categories with at least 10 observed cases among the farmers, screening for possible associations with the eight different crop categories was performed, calculating the Mantel-Haenszel odds ratios after stratification by age (four classes) and duration of farming (two classes). Adjustment for duration of farming might involve overadjustment; however, it allows the effect of specific exposures in growing a particular crop to be estimated. Third, all of the positive associations which emerged from the screening procedure with a P-value of $<0.10$ were studied with logistic regression. The logistic models for each cancer-crop association included categorized variables for age (nine classes) and duration of farming (three classes). Adjustment was also made for other possible crops that were related in the screening analyses to the cancer site of interest.

\section{Results}

The study was based on $1579(94.3 \%)$ cancer cases and $462(96.2 \%)$ referents, since personal identification data were incomplete for 98 cases and 18 referents. Altogether $888(56.2 \%)$ cancer cases and 274 $(59.3 \%)$ referents were classified as farmers. Farmers had a statistically significant decreased risk for lung cancer (OR 0.76), bladder cancer (OR 0.58), and melanoma (OR 0.19) (table 1). Nonstatistically significant excess risks were found for cancer of the stomach (OR 1.21), rectum (OR 1.44), skin (OR 4.34), and kidney (OR 1.39). Among the subjects with more than 10 years of farming, stomach and kidney cancer were significantly increased (OR 1.38 and OR 2.00, respectively); prostate cancer (OR 1.25) and leukemia (OR 1.29) were also slightly increased in this group.

Table 2 shows the results of cancer risks among licensed pesticide users for those cancer sites with more than two exposed cases. The odds ratios were calculated taking for comparison both nonfarmers $\left(\mathrm{OR}_{1}\right)$ and other farmers $\left(\mathrm{OR}_{2}\right)$. This choice was justified by the fact that nonlicensed farmers may actually be exposed to pesticides. The cancer site that was clearly increased among the licensed pesticide users was pancreatic cancer (6 exposed cases, 15 exposed referents, $\mathrm{OR}_{1} 2.34, \mathrm{OR}_{2} 2.89$ ); the excess was greater when the analysis was restricted to individuals with more than 10 years of farming $(O R, 3.78$, $\mathrm{OR}_{2}$ 5.18). In addition cancers of the stomach, rectum, and prostate appeared in excess among the li-

Table 2. Case-referent data on the association between cancers of different sites ${ }^{a}$ and license for pesticide use. [OR $1=0$ odds ratio comparing licensed farmers with nonfarmers (Mantel-Haenszel adjustment for age), $\mathrm{OR}_{2}=$ odds ratio comparing licensed farmers with other farmers (Mantel-Haenszel adjustment for age), $90 \% \mathrm{Cl}=90 \%$ confidence interval]

\begin{tabular}{|c|c|c|c|c|c|c|c|c|c|c|}
\hline & \multicolumn{5}{|c|}{ Licensed farmers } & \multicolumn{5}{|c|}{$\begin{array}{c}\text { Licensed farmers } \\
\text { (>10 years of farming) }\end{array}$} \\
\hline & $\begin{array}{c}\text { Numb } \\
\text { of } \\
\text { expos } \\
\text { case }\end{array}$ & $\mathrm{OR}_{1}$ & $\begin{array}{l}90 \% \mathrm{Cl} \\
\text { for } \mathrm{OR}_{1}\end{array}$ & $\mathrm{OR}_{2}$ & $\begin{array}{l}90 \% \mathrm{Cl} \\
\text { for } \mathrm{OR}_{2}\end{array}$ & $\begin{array}{l}\text { Number } \\
\text { of } \\
\text { exposed } \\
\text { cases }\end{array}$ & $O R_{1}$ & $\begin{array}{l}90 \% \mathrm{Cl} \\
\text { for } \mathrm{OR}_{1}\end{array}$ & $\mathrm{OR}_{2}$ & $\begin{array}{l}90 \% \mathrm{Cl} \\
\text { for } \mathrm{OR}_{2}\end{array}$ \\
\hline \multicolumn{11}{|l|}{ Cases } \\
\hline $\begin{array}{l}\text { Stomach } \\
\text { Rectum and sigma } \\
\text { Pancreas } \\
\text { Lung } \\
\text { Prostate }\end{array}$ & $\begin{array}{r}15 \\
5 \\
6 \\
14 \\
5\end{array}$ & $\begin{array}{l}1.79 \\
2.91 \\
2.34 \\
0.70 \\
1.53\end{array}$ & $\begin{array}{l}0.88-3.64 \\
0.92-8.29 \\
0.83-6.06 \\
0.34-1.41 \\
0.50-4.14\end{array}$ & $\begin{array}{l}1.43 \\
2.01 \\
2.89^{\star} \\
0.87 \\
1.60\end{array}$ & $\begin{array}{l}0.71-2.86 \\
0.66-5.39 \\
1.02-7.52 \\
0.42-1.80 \\
0.53-4.33\end{array}$ & $\begin{array}{r}12 \\
4 \\
6 \\
11 \\
5\end{array}$ & $\begin{array}{l}2.62^{\star} \\
4.22^{\star} \\
3.78^{\star} \\
0.89 \\
2.68\end{array}$ & $\begin{array}{l}1.11-6.30 \\
1.08-14.7 \\
1.24-11.0 \\
0.38-2.14 \\
0.81-8.23\end{array}$ & $\begin{array}{l}1.77 \\
2.82 \\
5.18^{\star} \\
1.07 \\
2.13\end{array}$ & $\begin{array}{l}0.75-4.25 \\
0.75-9.32 \\
1.55-16.7 \\
0.44-2.67 \\
0.64-6.49\end{array}$ \\
\hline Referents & 15 & . & . & . & . & 9 & . & . & . & . \\
\hline
\end{tabular}

a Only those site series with more than two exposed cases are presented.

* $\mathrm{P}<0.10$ (two-sided). 
censed farmers, especially among individuals with more than 10 years of farming. However, the excess was significant only for stomach and rectal cancer when nonfarmers were taken for comparison $\left(\mathrm{OR}_{1}\right.$ 2.62 and $\mathrm{OR}$ 4.22).

Out of 274 referents categorized as farmers, 140 $(51 \%)$ were classified as farming wheat, $130(47.4 \%)$ grapes, $135(49.3 \%)$ olives, $97(35.4 \%)$ hazelnuts, $140(51 \%)$ fruit, $66(24.1 \%)$ potatoes, $155(56.6 \%)$ corn, and $37(13.5 \%)$ strawberries. Only 13 cancer sites were admitted to screening for crop-cancer site associations through the Mantel-Haenszel technique. Melanoma, nonmelanotic skin tumors, Hodgkin's lymphoma, and multiple myeloma were eliminated because fewer than 10 cases were observed among the farmers. The screening, applied to 104 potential relationships ( 13 cancer sites $\times 8$ crops) (tables 3 and $4)$, revealed the following nine statistically significant associations $(P<0.10$, two-sided $)$ to be further studied through logistic regression: wheat-rectum (OR 2.61), wheat-prostate (OR 3.45), olives-kidney (OR 3.16) (table 3), fruit-colon (OR 3.18), fruit-bladder (OR 4.15), potatoes-kidney (OR 2.42), corn-prostate (OR 1.67), corn-bladder (OR 3.07), and strawberries-colon (OR 2.48) (table 4).

Table 5 presents the results of the logistic regression analysis for each cancer-crop association. Adjustment was made for age and duration of farming, and also for other crops positive in the Mantel-Haenszel screening. In the examination for colon cancer among farmers, the association with fruit was confirmed (OR 3.85) and an exposure-response effect was present (OR 4.40 in the high-exposure category). Furthermore, the association was stronger in the age group below 70 years (OR 7.81 for all those exposed and 12.5 for those highly exposed). The colon cancer-strawberries association was less consistent. The overall odds ratio (OR 2.69) was reduced after

Table 3. Case-referent data on the association between farming of different crops and various cancer sites. [OR = Mantel-Haenszel odds ratio adjusted for age $(35-49,50-59,60-69,70-80$ years) and duration of farming $(\leq 10,>10$ years), $90 \% \mathrm{Cl}=\mathrm{exact}$ $90 \%$ confidence interval]

\begin{tabular}{|c|c|c|c|c|c|c|c|c|c|}
\hline & \multicolumn{3}{|c|}{ Wheat } & \multicolumn{3}{|c|}{ Grapes } & \multicolumn{3}{|c|}{ Olives } \\
\hline & $N$ & OR & $90 \% \mathrm{Cl}$ & $\mathrm{N}$ & OR & $90 \% \mathrm{Cl}$ & $N$ & OR & $90 \% \mathrm{Cl}$ \\
\hline \multicolumn{10}{|l|}{ Cases } \\
\hline $\begin{array}{l}\text { Esophagus } \\
\text { Stomach } \\
\text { Colon } \\
\text { Rectum and sigma } \\
\text { Pancreas } \\
\text { Larynx } \\
\text { Lung } \\
\text { Prostate } \\
\text { Bladder } \\
\text { Kidney } \\
\text { Brain } \\
\text { Non-Hodgkin's Iymphoma } \\
\text { Leukemia }\end{array}$ & $\begin{array}{r}14 \\
107 \\
31 \\
27 \\
21 \\
21 \\
134 \\
55 \\
22 \\
19 \\
8 \\
6 \\
21\end{array}$ & $\begin{array}{l}0.84 \\
1.03 \\
0.90 \\
2.61^{\star} \\
1.47 \\
1.02 \\
0.79 \\
3.45^{\star} \\
1.64 \\
1.49 \\
1.21 \\
0.54 \\
0.94\end{array}$ & $\begin{array}{l}0.29-2.58 \\
0.66-1.59 \\
0.44-1.86 \\
1.10-6.41 \\
0.60-3.57 \\
0.41-2.54 \\
0.52-1.22 \\
1.78-6.88 \\
0.69-3.96 \\
0.50-4.88 \\
0.18-14.9 \\
0.12-2.66 \\
0.41-2.22\end{array}$ & $\begin{array}{r}15 \\
97 \\
29 \\
18 \\
19 \\
18 \\
132 \\
43 \\
17 \\
17 \\
7 \\
8 \\
16\end{array}$ & $\begin{array}{l}1.76 \\
0.87 \\
1.03 \\
0.75 \\
1.46 \\
0.88 \\
0.90 \\
1.23 \\
0.81 \\
1.12 \\
0.91 \\
2.79 \\
0.50\end{array}$ & $\begin{array}{l}0.56-6.22 \\
0.54-1.41 \\
0.50-2.16 \\
0.33-1.78 \\
0.57-3.89 \\
0.35-2.30 \\
0.59-1.38 \\
0.66-2.32 \\
0.35-1.93 \\
0.40-3.48 \\
0.20-6.46 \\
0.51-20.0 \\
0.22-1.13\end{array}$ & $\begin{array}{r}12 \\
97 \\
25 \\
18 \\
22 \\
22 \\
122 \\
43 \\
16 \\
21 \\
7 \\
8 \\
17\end{array}$ & $\begin{array}{l}0.81 \\
1.01 \\
0.61 \\
0.76 \\
1.68 \\
1.41 \\
0.72 \\
1.18 \\
0.73 \\
3.16^{\star} \\
0.90 \\
2.17 \\
0.63\end{array}$ & $\begin{array}{l}0.31-2.17 \\
0.54-1.23 \\
0.32-1.14 \\
0.37-1.57 \\
0.75-3.83 \\
0.61-3.28 \\
0.49-1.05 \\
0.68-2.06 \\
0.34-1.56 \\
1.00-12.1 \\
0.20-5.53 \\
0.51-11.5 \\
0.30-1.31\end{array}$ \\
\hline Referents & 140 & . & . & 130 & . & . & 135 & . & . \\
\hline
\end{tabular}

${ }^{\star} \mathrm{P}<0.10$ (two-sided).

Table 4. Case-referent data on the association between farming of different crops and various cancer sites. [OR = Mantel-Haenszel odds ratio adjusted for age $(35-49,50-59,60-69,70-80$ years) and duration of farming $(\leq 10,>10$ years), $90 \% \mathrm{Cl}=\mathrm{exact}$ $90 \%$ confidence interval]

\begin{tabular}{|c|c|c|c|c|c|c|c|c|c|c|c|c|c|c|c|}
\hline & \multicolumn{3}{|c|}{ Hazelnuts } & \multicolumn{3}{|c|}{ Fruit } & \multicolumn{3}{|c|}{ Potatoes } & \multicolumn{3}{|c|}{ Corn } & \multicolumn{3}{|c|}{ Strawberries } \\
\hline & $N$ & OR & $90 \% \mathrm{Cl}$ & $N$ & OR & $90 \% \mathrm{Cl}$ & $\mathrm{N}$ & OR & $90 \% \mathrm{Cl}$ & $N$ & OR & $90 \% \mathrm{Cl}$ & $N$ & OR & $90 \% \mathrm{Cl}$ \\
\hline \multicolumn{16}{|l|}{ Cases } \\
\hline $\begin{array}{l}\text { Esophagus } \\
\text { Stomach } \\
\text { Colon } \\
\text { Rectum and sigma } \\
\text { Pancreas } \\
\text { Larynx } \\
\text { Lung } \\
\text { Prostate } \\
\text { Bladder } \\
\text { Kidney } \\
\text { Brain } \\
\text { Non-Hodgkin's lymphoma } \\
\text { Leukemia }\end{array}$ & $\begin{array}{r}10 \\
72 \\
17 \\
11 \\
10 \\
16 \\
105 \\
19 \\
9 \\
5 \\
4 \\
4 \\
5 \\
14\end{array}$ & $\begin{array}{l}1.44 \\
1.05 \\
0.78 \\
0.61 \\
0.66 \\
1.07 \\
1.17 \\
0.67 \\
0.61 \\
0.36^{*} \\
1.15 \\
1.58 \\
1.06\end{array}$ & $\begin{array}{l}0.62-3.27 \\
0.74-1.48 \\
0.44-1.36 \\
0.30-1.19 \\
0.31-1.34 \\
0.56-2.02 \\
0.85-1.60 \\
0.39-1.14 \\
0.28-1.24 \\
0.12-0.94 \\
0.29-4.14 \\
0.46-5.23 \\
0.55-2.03\end{array}$ & $\begin{array}{r}13 \\
111 \\
45 \\
24 \\
21 \\
19 \\
129 \\
36 \\
29 \\
18 \\
5 \\
6 \\
19\end{array}$ & $\begin{array}{l}1.12 \\
1.22 \\
3.18^{*} \\
1.25 \\
1.17 \\
0.75 \\
0.88 \\
0.92 \\
4.15^{*} \\
1.80 \\
0.56 \\
0.86 \\
0.88\end{array}$ & $\begin{array}{l}0.49-2.61 \\
0.87-1.71 \\
1.74-6.06 \\
0.68-2.32 \\
0.61-2.28 \\
0.38-1.46 \\
0.64-1.20 \\
0.57-1.49 \\
1.89-9.96 \\
0.77-4.45 \\
0.13-2.20 \\
0.24-3.10 \\
0.47-1.66\end{array}$ & $\begin{array}{r}6 \\
58 \\
19 \\
14 \\
14 \\
9 \\
72 \\
19 \\
11 \\
11 \\
3 \\
6 \\
9\end{array}$ & $\begin{array}{l}0.97 \\
1.35 \\
1.52 \\
1.73 \\
1.99 \\
1.04 \\
1.18 \\
0.98 \\
1.36 \\
2.42^{*} \\
1.18 \\
3.12 \\
0.92\end{array}$ & $\begin{array}{l}0.36-2.42 \\
0.92-1.97 \\
0.85-2.69 \\
0.88-3.35 \\
0.98-3.97 \\
0.46-2.25 \\
0.83-1.69 \\
0.56-1.69 \\
0.65-2.76 \\
1.04-5.61 \\
0.24-4.74 \\
0.94-10.7 \\
0.42-1.91\end{array}$ & $\begin{array}{r}17 \\
119 \\
39 \\
29 \\
24 \\
29 \\
146 \\
49 \\
29 \\
18 \\
8 \\
7 \\
21\end{array}$ & $\begin{array}{l}1.89 \\
1.22 \\
1.42 \\
1.50 \\
1.40 \\
1.68 \\
0.92 \\
1.67^{\star} \\
3.07^{*} \\
1.45 \\
2.02 \\
1.14 \\
0.91\end{array}$ & $\begin{array}{l}0.78-5.03 \\
0.87-1.70 \\
0.83-2.49 \\
0.80-2.86 \\
0.73-2.79 \\
0.86-3.38 \\
0.67-1.26 \\
1.01-2.80 \\
1.42-7.31 \\
0.63-3.53 \\
0.45-14.0 \\
0.32-4.44 \\
0.49-1.72\end{array}$ & $\begin{array}{r}5 \\
28 \\
16 \\
6 \\
7 \\
3 \\
34 \\
8 \\
8 \\
3 \\
1 \\
2 \\
4\end{array}$ & $\begin{array}{l}1.48 \\
1.05 \\
2.48^{\star} \\
1.11 \\
1.38 \\
0.57 \\
0.89 \\
0.70 \\
1.87 \\
0.80 \\
0.71 \\
1.38 \\
0.71\end{array}$ & $\begin{array}{l}0.49-3.93 \\
0.64-1.72 \\
1.30-4.65 \\
0.42-2.62 \\
0.55-3.20 \\
0.14-1.76 \\
0.55-1.43 \\
0.31-1.47 \\
0.79-4.15 \\
0.19-2.61 \\
0.03-4.89 \\
0.20-5.91 \\
0.22-1.88\end{array}$ \\
\hline Referents & 97 & . & . & 140 & . & . & 66 & . & . & 155 & . & . & 37 & . & $\cdot$ \\
\hline
\end{tabular}

* $P<0.10$ (two-sided). 
Table 5. Associations between crops and cancers at different sites among the farmers emerging in the analysis with the MantelHaenszel procedure. ( $\mathrm{N}=$ number of exposed cases, $\mathrm{OR}=$ odds ratio, $90 \% \mathrm{Cl}=90 \%$ confidence interval)

\begin{tabular}{|c|c|c|c|c|c|c|}
\hline \multirow[b]{3}{*}{ Neoplasms-crop } & \multicolumn{6}{|c|}{ Exposure } \\
\hline & \multicolumn{3}{|c|}{ Any } & \multicolumn{3}{|c|}{ High } \\
\hline & $\begin{array}{l}\text { Number } \\
\text { of } \\
\text { exposed } \\
\text { cases }\end{array}$ & OR & $90 \% \mathrm{Cl}$ & $\begin{array}{l}\text { Number } \\
\text { of } \\
\text { exposed } \\
\text { cases }\end{array}$ & OR & $90 \% \mathrm{Cl}$ \\
\hline \multicolumn{7}{|l|}{ Colon-fruit } \\
\hline Comparison $1^{a}$ & 45 & 3.85 & $1.91-5.99$ & 23 & 4.40 & $2.20-8.80$ \\
\hline $\begin{array}{l}35-69 \text { years } \\
70-80 \text { years }\end{array}$ & $\begin{array}{l}28 \\
17\end{array}$ & $\begin{array}{l}7.81 \\
1.87\end{array}$ & $\begin{array}{l}2.88-21.2 \\
0.89-3.91\end{array}$ & $\begin{array}{r}15 \\
8\end{array}$ & $\begin{array}{c}12.5 \\
2.14\end{array}$ & $\begin{array}{l}3.79-41.3 \\
0.85-5.41\end{array}$ \\
\hline Comparison $2^{\mathrm{b}}$ & 45 & 2.96 & $1.64-5.34$ & 23 & 3.97 & $1.88-8.35$ \\
\hline \multicolumn{7}{|l|}{ Colon-strawberries } \\
\hline Comparison $1^{a}$ & 16 & 2.69 & $1.49-4.85$ & 3 & 1.04 & $0.35-3.13$ \\
\hline $\begin{array}{l}35-69 \text { years } \\
70-80 \text { years }\end{array}$ & $\begin{array}{r}10 \\
6\end{array}$ & $\begin{array}{l}4.26 \\
1.65\end{array}$ & $\begin{array}{l}1.75-10.4 \\
0.69-3.94\end{array}$ & $\begin{array}{l}2 \\
1\end{array}$ & $\begin{array}{l}1.14 \\
0.62\end{array}$ & $\begin{array}{l}0.23-5.72 \\
0.10-3.75\end{array}$ \\
\hline Comparison $2^{\mathrm{b}}$ & 16 & 1.96 & $1.06-3.61$ & 3 & 0.59 & $0.19-1.88$ \\
\hline \multicolumn{7}{|c|}{ Rectum and sigma-wheat } \\
\hline Comparison $1^{\mathrm{a}}$ & 27 & 1.92 & $0.91-4.07$ & 14 & 1.93 & $0.85-4.77$ \\
\hline \multicolumn{7}{|l|}{ Prostate-wheat } \\
\hline $\begin{array}{l}\text { Comparison } 1^{\mathrm{a}} \\
\text { Comparison } 2^{\mathrm{b}}\end{array}$ & $\begin{array}{l}55 \\
55\end{array}$ & $\begin{array}{l}2.80 \\
2.49\end{array}$ & $\begin{array}{l}1.51-5.16 \\
1.30-4.79\end{array}$ & $\begin{array}{l}26 \\
26\end{array}$ & $\begin{array}{l}3.07 \\
2.68\end{array}$ & $\begin{array}{l}1.46-6.41 \\
1.19-6.02\end{array}$ \\
\hline \multicolumn{7}{|l|}{ Prostate-corn } \\
\hline $\begin{array}{l}\text { Comparison } 1^{\mathrm{a}} \\
\text { Comparison } 2^{\mathrm{b}}\end{array}$ & $\begin{array}{l}49 \\
49\end{array}$ & $\begin{array}{l}1.70 \\
1.31\end{array}$ & $\begin{array}{l}1.10-2.75 \\
0.80-2.18\end{array}$ & $\begin{array}{l}32 \\
32\end{array}$ & $\begin{array}{l}1.83 \\
1.28\end{array}$ & $\begin{array}{l}1.08-3.16 \\
0.70-2.33\end{array}$ \\
\hline \multicolumn{7}{|l|}{ Bladder-fruit } \\
\hline Comparison $1^{\mathrm{a}}$ & 29 & 3.97 & $1.92-8.23$ & 12 & 3.57 & $1.51-8.42$ \\
\hline $\begin{array}{l}35-69 \text { years } \\
70-80 \text { years }\end{array}$ & $\begin{array}{l}13 \\
16\end{array}$ & $\begin{array}{l}6.38 \\
3.34\end{array}$ & $\begin{array}{l}1.70-24.0 \\
1.37-8.12\end{array}$ & $\begin{array}{l}5 \\
7\end{array}$ & $\begin{array}{l}5.64 \\
2.93\end{array}$ & $\begin{array}{l}1.20-26.5 \\
1.03-8.31\end{array}$ \\
\hline Comparison $2^{\mathrm{b}}$ & 29 & 3.03 & $1.41-6.53$ & 12 & 2.52 & $0.99-6.41$ \\
\hline \multicolumn{7}{|l|}{ Bladder-corn } \\
\hline $\begin{array}{l}\text { Comparison } 1^{\mathrm{a}} \\
\text { Comparison } 2^{\mathrm{b}}\end{array}$ & $\begin{array}{l}29 \\
29\end{array}$ & $\begin{array}{l}3.20 \\
2.15\end{array}$ & $\begin{array}{l}1.55-6.60 \\
1.00-4.64\end{array}$ & $\begin{array}{l}13 \\
13\end{array}$ & $\begin{array}{l}2.38 \\
1.79\end{array}$ & $\begin{array}{l}1.03-5.53 \\
0.71-4.50\end{array}$ \\
\hline \multicolumn{7}{|l|}{ Kidney-olives } \\
\hline $\begin{array}{l}\text { Comparison } 1^{\mathrm{a}} \\
\text { Comparison } 2^{\mathrm{b}}\end{array}$ & $\begin{array}{l}21 \\
21\end{array}$ & $\begin{array}{l}2.99 \\
3.20\end{array}$ & $\begin{array}{l}1.03-8.66 \\
1.09-9.40\end{array}$ & $\begin{array}{l}10 \\
10\end{array}$ & $\begin{array}{l}2.47 \\
2.69\end{array}$ & $\begin{array}{l}0.76-8.03 \\
0.81-8.89\end{array}$ \\
\hline \multicolumn{7}{|l|}{ Kidney-potatoes } \\
\hline $\begin{array}{l}\text { Comparison } 1^{\mathrm{a}} \\
\text { Comparison } 2^{\mathrm{b}}\end{array}$ & $\begin{array}{l}11 \\
11\end{array}$ & $\begin{array}{l}2.17 \\
2.30\end{array}$ & $\begin{array}{l}1.05-4.51 \\
1.10-4.83\end{array}$ & $\begin{array}{l}4 \\
4\end{array}$ & $\begin{array}{l}2.22 \\
2.14\end{array}$ & $\begin{array}{l}0.77-6.40 \\
0.73-6.26\end{array}$ \\
\hline
\end{tabular}

a Comparison with unexposed farmers; $\mathrm{OR}$ and $90 \% \mathrm{Cl}$ from logistic models including age (nine-year classes) and duration of farming $(0-9,10-19,20-25$ years).

- Comparison with unexposed farmers; OR from logistic models which also include other crops positive in the Mantel-Haenszel screening.

adjustment for fruit (OR 1.96), and no exposure-response effect was found. However a high odds ratio was found for the age group below 70 years for those in the "any" strawberries category (OR 4.26).

The logistic regression analysis did not substantiate the association between cancer of the rectum and wheat (OR 1.92, 90\% CI 0.91-4.07). The association between prostate cancer and wheat (OR 2.80) was confirmed, and an exposure response was present (OR 3.07 for the high-exposure group). The association of prostatic cancer with corn seemed spurious since the odds ratio was reduced when exposure to wheat was introduced into the logistic model.

The association of bladder cancer with fruit remained in the logistic analysis (OR 3.97) and was stronger among younger subjects (OR 6.38). No exposure response was found, however. Bladder cancer was also associated with corn production (OR 3.20 ), but the odds ratio was reduced after adjustment for fruit (OR 2.15), and no dose-response effect was detected.

Kidney cancer was associated with growing olives and potatoes (OR 2.99 and 2.17, respectively), and both associations remained when the two variables where considered in the same logistic model. Increased odds ratios were found in the high exposure categories, but the confidence intervals were wide.

In summary, on the basis of the logistic procedure, the strength of the evidence was higher for the following five associations: colon-fruit, prostate-wheat, 
bladder-fruit, kidney-olives, and kidney-potatoes. We performed an additional analysis taking nonfarmers as the reference category, instead of unexposed farmers, while adjusting for age. The associations prostate cancer-wheat (OR 1.54, 90\%CI 1.05-2.25), kidney cancer-olives (OR 2.28, 90\%CI 1.24-4.18), and kidney cancer-potatoes (OR 3.04, 90\% CI 1.466.33) were still statistically significant. Colon cancer (OR $1.32,90 \% \mathrm{CI} 0.89-1.95$ ) and bladder cancer (OR $0.92,90 \% \mathrm{CI} 0.59-1.43$ ) were no longer associated with the category of fruit growers in this comparison.

\section{Discussion}

In this study cancer risks were investigated among all farmers as a group, among licensed pesticide users, and among farmers engaged in growing specific crops. The rationale for the latter approach was similar to that commonly used in industrial settings (ie, the analysis of cancer risk in different job categories gives the opportunity to examine the role of specific occupational exposures or it might indicate clues for further studies). Similarly, examining farmers according to the type of crops might help to identify possible agricultural exposures of potential etiologic interest.

The farmers in this study had mortality deficits of lung and bladder cancer but an increased risk of stomach cancer. These results are well in agreement with previous findings in other countries (2). In particular, stomach cancer was increased among farmers with more than 10 years of occupational activity and among those licensed for pesticide use. In Italy gastric cancer, although displaying a constant decrease over time, still represents a leading cause of death, and rural areas show a $10 \%$ higher rate than urban areas $(6,7)$. Farmers may be exposed to a number of suspected etiologic factors for stomach cancer, among which are nitrate fertilizers, nitrosable pesticides, and various types of dusts.

Pancreatic cancer was in excess among licensed pesticide users in this study. Deaths from cancer of the pancreas have been reported to be increased in two studies of workers employed in the grain industry with potential exposure to fumigants and insecticides $(8,9)$. Recently, a risk of pancreatic cancer was associated with exposure to DDT (dichlorodiphenyltrichloroethane) and related compounds in a case-referent study within a cohort of chemical workers (10). In the area of our study, farmers with a license for pesticide use were directly involved in spraying and applying agricultural chemicals, and an etiologic role for cancer of the pancreas is plausible.

Kidney cancer was increased among farmers with more than 10 years of activity and, specifically, among farmers raising olive trees and potatoes. Some studies have reported an increased risk of kidney cancer among farmers or occupational groups with pes- ticide exposure. Alavanja et al (11) reported increased mortality from kidney cancer among agricultural extension agents. Subsequently, a similar increase was found also among forest and soil conservationists (12). An elevated risk for kidney cancer was also seen among Swedish forestry workers (13). An increased risk of kidney cancer has been previously found among Italian farmers $(14,15)$. A recent mortality study of farmers in the United States (3) revealed an increased risk for renal cancer among white men. Exposure to pesticide and fertilizers was associated with increased renal cancer risk in a large case-referent study in Montreal (16). Potential occupational risk factors for renal cancer are hydrocarbons (17), asbestos (18), and gasoline exhaust (19). Inorganic lead compounds are established renal carcinogens in animals (20), and occupational exposure to inorganic lead has also been associated with an increased risk of kidney cancer (21). In Italy, lead arsenate was extensively used in agriculture, including olive cultivation, until the late 1960s. Exposure to lead arsenate, then, might be considered to explain the renal cancer excess. Specific studies, however, should address the issue of renal cancer among farmers in more detail.

Several studies among farmers have reported slight excesses of prostate cancer (2). Our data show an increased risk specifically related with wheat farming. Similarly, Siemiatycki et al (22) found an association between grain dust and cancer of the prostate. More generally, two previous studies have reported high prostate cancer rates among farmers $(23,24)$. Wiklund \& Holm (25) reported a positive time-related trend of prostate cancer among agricultural workers in Sweden. An increased incidence of prostate cancer has also recently been reported among nitrate fertilizer workers (26). Little is known about the etiologic factors of this cancer. Cadmium is a suspected prostate carcinogen (20). The presence of cadmium impurities in insecticides and fertilizers has been suggested as a possible explanation for the observed excesses among farmers (27).

Whereas farmers as a group had a decreased risk of bladder cancer, an elevated odds ratio was found for orchard farmers. Epidemiologic evidence linking bladder cancer and agricultural exposures is limited. Agricultural workers have low mortality from and low incidence of bladder cancer and other tobaccorelated diseases $(1,28)$. This observation may be explained by a lower prevalence of smoking among farmers $(29-31)$. In a case-referent study of bladder cancer among nonsmokers, the occupation of farmer was associated with an increased risk (32). A slight excess of bladder cancer was reported in one cohort of pesticide applicators (33). Crop spraying was associated with this tumor in one Canadian population-based study (34). In the United Kingdom, workers exposed to the rodenticide ANTU (alphanaphthylthiourea) containing beta-naphthylamine as an impurity had an increase of urothelial tumors (35). 
The incidence of bladder cancer was also increased in a cohort of workers engaged in the synthesis of the insecticide chlordimerform (36). Recently, an Italian case-referent study reported a strong association with herbicide exposure (37).

An association between fruit farming and colon cancer was detected in this study. Physically active jobs, including farming, have previously been associated with a decreased risk of colon cancer (38). Siemiatycki et al (22), however, investigating several site-exposure combinations, reported an increased risk of colon cancer in association with grain dust exposure. Increased risks were also reported among agricultural extension agents (11) and among soil and forest conservationists (12). The increased risk of rectal cancer among licensed pesticide users in this study was an unusual finding; previous studies reporting a similar association are lacking.

For both colon and bladder cancer there was a strong excess among the subjects employed in fruit production, and the risk was higher among the younger farmers. Many chemicals are normally employed in this agricultural practice but, in the absence of specific exposure information, it is difficult to determine the role of any specific agent. Mildly refined mineral oils should, however, be considered in more detail since these products have been extensively used as insecticides for the winter treatment of fruit trees. Untreated and mildly treated mineral oils are known carcinogens, and both digestive tract cancer and bladder cancer have been detected among exposed workers (20).

This study is based on death certificates and on exposure information previously recorded for primarily administrative purposes. Furthermore, the farming activities were assessed with an "ecological" approach rather than with the use of direct interviews, as in other studies on farmers (39-43). Two main validity issues arise, namely, possible misclassification of the disease entity and of the exposure status. Random misclassification is probable but would tend to bias the risk estimates toward the null (44) and, therefore, would underestimate the true risk ratio. Hematologic malignancies were not in excess in this study, in contrast to most other surveys of cancer among farmers. Some unreliability of the death certificates and exposure misclassification may explain the nonpositive results. Similarly, the observed discrepancy with regard to skin melanoma and other skin cancers may be partially explained by the known low accuracy of death certificates for cutaneous sites. On the other hand, a statistically significant deficit of melanoma has been observed among farmers in Alberta (45), whereas lip cancer was in excess in this group.

From a validity point of view the selection of referents is a matter of concern, especially since we have included cancer deaths in the reference series. In theory this may be considered a strategy leading to more conservative risk estimations. However, it might cause a bias towards false positive results among occupational groups with a lower risk for cancer, such as farmers. As a matter of fact, we have repeated several analyses using two alternative sets of controls, only noncancer deaths and only other cancer deaths. The results were very similar to those reported. For example, the odds ratio for stomach cancer for subjects with more than 10 years of farming ( 1.38 as reported in table 2 ) was 1.36 when noncancer deaths were used as the reference series and 1.40 when other cancer deaths were used.

The problem of multiple comparisons should be considered. Some of the significant associations were unexpected and may have been generated only by chance. This issue, however, has been specifically addressed in the epidemiologic literature, and it has been suggested that, as has been done in the present study, every association should nonetheless be evaluated independently $(46,47)$.

In conclusion, this study shows that, overall, farmers in central Italy have low rates of death from lung and bladder cancer, whereas stomach cancer is increased. This finding, together with the elevated odds ratio for pancreatic cancer observed among licensed pesticide users and the association between prostate cancer and wheat, are all consistent with findings of other studies. The excess of kidney cancer, particularly among olive and potato farmers, as well as the strong associations of colon and bladder cancer with orchard farming, are new findings. They warrant further investigation to identify preventable exposures.

\section{Acknowledgments}

We thank Dr Serra of Consornio Agrario-Viterbo for his collaboration in the data collection, $\mathrm{Dr} \mathrm{O}$ Axelson and Dr A Blair for their useful criticism of an early version of the manuscript, and Ms AM Emigli and $\operatorname{Dr} \mathrm{S}$ Levenstein for editing the manuscript.

\section{References}

1. Blair A, Malker H, Cantor KP, Burmeister L, Wiklund K. Cancer among farmers: a review. Scand J Work Environ Health 1985;11:397-407.

2. Blair A, Zahm SH. Cancer among farmers. In: Cordes DH, Rea DF, ed. Health hazards of farming. Philadelphia, PA: Hanely and Belfus Inc, 1991:335-54. (Occupational medicine: state of the art reviews; vol 6.)

3. Blair A, Dosemeci M, Heineman EF. Cancer and other causes of death among male and female farmers from twenty-three states. Am J Ind Med 1993;6:729-42.

4. Blair A, Zahm SH, Cantor KP, Stewart PA. Estimating exposure to pesticides in epidemiologic studies of cancer. In: Wang RGM, Franklin CA, Honeycutt RC, Reinert JC, ed. Biological monitoring for pesticide exposure. Washington, DC: American Chemical Society, 1989:38-46. (ACS symposium series; no 382.)

5. Mantel N, Haenszel W. Statistical aspects of the analysis of data from retrospective studies of disease. JNCI $1959 ; 22: 719-48$. 
6. Decarli A, La Vecchia C, Cislaghi C, Mezzanotte G, Marubini E. Descriptive epidemiology of gastric cancer in Italy. Cancer 1986;58:2560-9.

7. Buiatti E, Palli D, Bianchi S, Decarli A, Amadori D, Avellini C, et al. A case-control study of gastric cancer and diet in Italy: III. risk patterns by histologic type. Cancer 1991;48:369-74.

8. Thomas TL, Krekel S, Heid M. Proportionate mortality among male corn wet-milling workers. Int J Epidemiol 1985; 14:432-7.

9. Alavanja MCR, Blair A, Masters MN. Cancer mortality in the US flour industry. JNCI 1990;82:840-8.

10. Garabrant DH, Held J, Langholz B, Peters JM, Mack TM. DDT and related compounds and risk of pancreatic cancer. JNCI 1992;84:764-71.

11. Alavanja MCR, Blair A, Merkle S, Teske J, Eaton B Mortality among agricultural extension agents. Am J Ind Med 1988; 14:167-76.

12. Alavanja MCR, Blair A, Merkle S, Teske J, Eaton B, Reed B. Mortality among forest and soil conservationists. Arch Environ Health 1989;44:94-101.

13. Edling C, Granstam S. Causes of death among lumberjacks - a pilot study. J Occup Med 1980;22: $403-6$.

14. Ronco G, Costa G, Lynge E. Cancer risk among Danish and Italian farmers. Br J Ind Med 1992;49: $220-5$.

15. Faustini A, Forastiere F, Di Betta L, Magliola ME, Perucci CA. Cohort study of mortality among farmers and agricultural workers in central Italy. Med Lav 1993;84:31-41.

16. Siemiatycki J. Risk factors for cancer in the workplace. Boca Raton, FL: CRC Press, 1991.

17. Kadamani S, Asal NR, Nelson RY. Occupational hydrocarbon exposure and risk of renal cell carcinoma. Am J Ind Med 1989;15:131-41.

18. Smith AH, Shearn VI, Wood R. Asbestos and kidney cancer: the evidence supports a casual association. Am J Ind Med 1989;16:159 -66.

19. Partanen $T$, Heikkilä $P$, Hernberg $S$, Kauppinen $T$, Moneta G, Ojajärvi A. Renal cell cancer and occupational exposure to chemical agents. Scand J Work Environ Health $1991 ; 17: 231-9$.

20. International Agency for Research on Cancer (IARC). Overall evaluation of carcinogenicity: an updating of IARC monographs volumes 1 to 42 . Lyon: IARC, 1987. (IARC monographs on the evaluation of the carcinogenic risk of chemicals to humans; suppl 7.)

21. Steenland K, Selevan S, Landrigan P. The mortality of lead smelter workers: un update. Am J Public Health 1992;82:1641-4.

22. Siemiatycki J, Richardson L, Gérin M, Goldberg $M$, Dewar R, Désy M, et al. Associations between several sites of cancer and nine organic dusts: results from an hypothesis-generating case-control study in Montreal, 1979-1983. Am J Epidemiol 1986;123:23549.

23. Delzell E, Grufferman S. Mortality among white and nonwhite farmers in North Carolina, 1976--1978. Am J Epidemiol 1985;121:391 402 .

24. Brownson RC, Chang JC, Davis JR, Bagby JR. Occupational risk of prostate cancer: a cancer registrybased study. J Occup Med 1988;30:523-6.

25. Wiklund $\mathrm{K}$, Holm LE. Trends in cancer risks among Swedish agricultural workers. JNCI 1986;77:657--64

26. Hagmar L, Bellander T, Andersson C, Lindén K, At- tewell R, Möller T. Cancer morbidity in nitrate fertilizer workers. Occup Environ Health 1991;63:63-7.

27. Brownson RC, Reif JS, Chang JC, Davis JR. Cancer risks among Missouri farmers. Cancer 1989;64:2381-6.

28. Blair A, Hoar Zahm S, Pearce NE, Heineman EF, Fraumeni JF Jr. Clues to cancer etiology from studies of farmers. Scand J Work Environ Health 1992;18: $209-15$.

29. Covey LS, Wynder EL. Smoking habits and occupational status. J Occup Med 1981;23:537-42.

30. Stellman SD, Boffetta P, Garfinkel L. Smoking habits of 800,000 American men and women in relation to their occupations. Am J Ind Med 1988;13:43-58.

31. Levin LI, Silverman DT, Hartge P, Fears TR, Hoover RN. Smoking patterns by occupation and duration of employment. Am J Ind Med 1990;17:711-25.

32. Kabat GC, Dieck GS, Wynder EL. Bladder cancer in nonsmokers. Cancer 1986;57:362-7.

33. Wang HH, MacMahon B. Mortality of pesticide applicators. J Occup Med 1979;21:741 -4.

34. Howe GR, Burch JD, Miller AB, Cook GM, Esteve $\mathrm{J}$, Morrison B, et al. Tobacco use, occupation, coffee, various nutrients, and bladder cancer. JNCI 1980; 64:701-13.

35. Davies JM, Thomas HF, Manson D. Bladder tumors among rodent operatives handling ANTU. Br Med J 1982;285:927-31.

36. Popp W, Schmieding W, Speck M, Vahrenholz C, Norpoth K. Incidence of bladder cancer in a cohort of workers exposed to 4-chloro-o-toluidine while synthesising chlordimeform. Br J Ind Med 1992;49:529-31.

37. La Vecchia C, Negri E, D’Avanzo B, Franceschi S. Occupation and the risk of bladder cancer. Int $\mathbf{J}$ Epidemiol 1990;19:264-8.

38. Fredriksson M, Bengtsson NO, Hardell L, Axelson O. Colon cancer, physical activity, and occupational exposures: a case-control study. Cancer 1989;63:183842.

39. Blair A, Thomas TL. Leukemia among Nebraska farmers: a death certificate study. Am J Epidemiol 1979; 110:264-73.

40. Burmeister LF, Van Lier S, Isacson P. Leukemia amd farm practices in Iowa. Am J Epidemiol 1982;115: $720-8$.

41. Burmeister LF, Everett GD, Van Lier SF, Isacson P Selected cancer mortality and farm practices in Iowa. Am J Epidemiol 1983;118:72-7.

42. Cantor KP. Farming and mortality from non-Hodgkin's lymphoma: a case-control study. Int J Cancer 1982;29:239- 47.

43. Cantor KP, Blair A. Farming and mortality from multiple myeloma: a case-control study with the use of death certificates. JNCI 1984;72:251-5.

44. Checkoway H, Pearce NE, Crawford-Brown DJ. Research methods in occupational epidemiology. New York, NY: Oxford University Press, 1989.

45. Fincham SM, Hanson J, Berkel J. Patterns and risks of cancer in farmers in Alberta. Cancer 1992;69: $1276-83$

46. Rothman KJ. No adjustments are needed for multiple comparisons. Epidemiology 1990;1:43-6.

47. Poole C. Multiple comparisons? No problem! Epidemiology $1991 ; 2: 241-3$.

Received for publication: 5 March 1993 